\title{
Resistance of Arylsulfatase to Contamination of Soil by Heavy Metals
}

\author{
Jadwiga Wyszkowska*, Karol Wieczorek, Jan Kucharski \\ University of Warmia and Mazury in Olsztyn, Department of Microbiology, \\ Plac Lodzki 3, 10-727 Olsztyn, Poland
}

Received: 26 May 2015

Accepted: 31 October 2015

\begin{abstract}
Contamination of soils by heavy metals is a severe problem because of disturbances caused in the functioning of the soil and the whole ecosystem. Therefore, the aim of our research was to determine the influence of contamination of soil by zinc, copper, nickel, cadmium, and lead on the activity of arylsulfatase. A novel element of the study is a comparison of the response of arylsulfatase to five heavy metals in three soils with two $\mathrm{pH}$ ranges: 7.0 and 5.5. The studies were carried out under laboratory conditions. The soils (loamy sand, sandy loam, sandy clay loam), with pH 7.0 and 5.5 and contaminated with zinc, copper, nickel, cadmium, and lead were incubated for 30,60, and 120 days. After each period, the activity of arylsulfatase was determined. Base on the activity of arylsulfatase, a resistance index of arylsulfatase (RS) to contamination with heavy metals was calculated. The highest activity of arylsulfatase was found in sandy clay loam, while the lowest was found in loamy sand. A significant correlation between the resistance of the enzyme and the level of contamination of the soil with heavy metals was proved. Arylsulfatase was most sensitive to the effects of zinc, copper, and nickel, while cadmium exerted a somewhat weaker influence and lead the least. The enzyme exhibited a higher resistance to the influence of heavy metals in neutral soils than in acidic soils. The toxic effect of heavy metals can be ordered as follows: zinc $>$ copper $>$ nickel $>$ lead $>$ cadmium.
\end{abstract}

Keywords: enzyme activity, environmental disturbance, soil contamination, trace elements

\section{Introduction}

Soil is a non-renewable natural resource. A great increase in living standards contributes to the degradation of soil [1] by worsening its physical, chemical, and biological properties $[2,3]$. Contamination of soil by heavy metals is one of the most frequent, and thus one of the greatest, environmental nuisances $[4,5]$. The problem of contamination of the soil with heavy metals has consti-

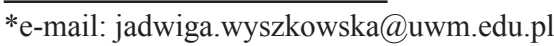

tuted a serious threat to the environment for many years [6]. It is estimated that in Europe formations contaminated with heavy metals [7] amount to $34.8 \%$ of degraded soils. Throughout the European continent, contents of zinc in $1 \mathrm{~kg}$ of soil oscillated in the range of $4 \div 2,832 \mathrm{mg}$, $1 \div 421 \mathrm{mg}$ copper, $1 \div 2,565 \mathrm{mg}$ nickel, $0.010 \div 23.60 \mathrm{mg}$ cadmium, and $1.5 \div 5,200 \mathrm{mg}$ lead [8]. The amount of heavy metals in the soil is closely correlated with the level of industrialisation. A key part in soil contamination with heavy metals is played by arsenic, cadmium, copper, mercury, nickel, lead, and zinc [8]. Expansive agriculture accelerates the degradation of agricultural areas, manifesting itself by a limitation of their productivity, and therefore 
Table 1. Physico-chemical properties of soils used in the experiment.

\begin{tabular}{|c|c|c|c|c|c|c|c|c|c|}
\hline \multirow{4}{*}{ Soil type ${ }^{1}$} & & oil texture & & \multirow{4}{*}{$\begin{array}{c}\mathrm{C}_{\text {org }} \\
{[\mathrm{g} / \mathrm{kg}]}\end{array}$} & \multirow{4}{*}{$\mathrm{pH}_{\mathrm{KCl}}$} & \multirow{3}{*}{$\mathrm{HAC}$} & \multirow{3}{*}{ TEB } & \multirow{3}{*}{ CEC } & \multirow{4}{*}{$\mathrm{BS}[\%]$} \\
\hline & \multicolumn{3}{|c|}{ [grain diameter, $\mathrm{mm}$ ] } & & & & & & \\
\hline & $2-0.05$ & $0.05-0.002$ & $<0.002$ & & & & & & \\
\hline & \multicolumn{3}{|c|}{ Content $[\%]$} & & & \multicolumn{3}{|c|}{$[\mathrm{mmol}(+) / \mathrm{kg} \mathrm{DM}$ of soil $]$} & \\
\hline \multirow{2}{*}{ LS } & 80 & 12 & 8 & 5.05 & 7.0 & 10.50 & 55.00 & 65.50 & 83.97 \\
\hline & 80 & 12 & 8 & 5.05 & 5.5 & 21.75 & 47.00 & 68.75 & 68.36 \\
\hline \multirow{2}{*}{ SL } & 72 & 21 & 7 & 7.05 & 7.0 & 8.00 & 111.0 & 119.0 & 93.28 \\
\hline & 74 & 16 & 10 & 5.75 & 5.5 & 25.50 & 17.00 & 42.50 & 40.00 \\
\hline \multirow{2}{*}{$\mathrm{SCL}$} & 56 & 23 & 21 & 14.33 & 7.0 & 6.00 & 190.0 & 196.0 & 96.94 \\
\hline & 56 & 23 & 21 & 14.33 & 5.5 & 12.75 & 107.0 & 119.7 & 89.35 \\
\hline
\end{tabular}

${ }^{1} \mathrm{LS}$ - loamy sand, SL - sandy loam, SCL - sandy clay loam

decreases in the yield and quality of crops [9]. Heavy metals constitute an actual danger for not only the natural environment, but also human health [10]. There are many causes (of an anthropogenic character) of the presence of heavy metals in soils, including wastewater management, using composts consisting of organic municipal waste containing heavy metals [11], utilisation of sewage sludge in agriculture, emissions of combustion gas into the atmosphere followed by deposition in the form of dusts to the soil, the formation of new landfills for municipal and industrial waste and the operation of existing ones [12], and the production and use of plant pesticides and fertilisers [13].

The activity of soil enzymes is considered one of the most important measures of soil quality [14]. Soil enzymes perform as catalysts, accelerating the reactions of metabolic processes that are parts of the cycles of biogenic elements, the biodegradation of pollutants (including limitation of the influence of heavy metals), maintaining homeostasis in the soil. The enzymes also participate in transforming chemical compounds into forms available for higher organisms [15].

More than $95 \%$ of total sulfur content in the soil occurs as esters and in organic form. In such a state, this element is unavailable for plants. Mineralisation of sulfur may be carried out by microorganisms, and therefore their role in the sulfur cycle is very important $[16,17]$.

Enzyme activity, including arylsulfatase activity, is one of the most often used parameters for evaluating soil conditions $[18,19]$. Arylsulfatase (EC 3.1.6.1.) is an enzyme belonging to the class of hydrolases [18] responsible for the hydrolysis of sulfate esters containing an aryl. As a result of hydrolysis, sulphate (VI) ions are liberated according to the following equation: $\mathrm{R}-\mathrm{C}-\mathrm{O}-\mathrm{SO}_{3}{ }^{-}+\mathrm{H}_{2} \mathrm{O}$ $\rightarrow \mathrm{R}-\mathrm{C}-\mathrm{OH}+\mathrm{SO}_{4}^{2-}+\mathrm{H}^{+}$. This enzyme plays an important role in the sulfur cycle, and is utilised as a measure for the mineralisation of this element in the soil [13]. Arylsulfatase is a very important enzyme because of its commonness in soil and delivery of sulfur to plants in the oxidation process. The high level of sulfurs VI sulfate and nitrogen nitrates $\mathrm{V}$ in soil inhibite arylsulfatase activity [20]. Activity of arylsulfatase also depends on cultivated species of plants, soil type, soil use, and contamination with heavy metals [21].

The aim of our research was to evaluate the possibility of using the activity of arylsulfatase as a microbiological indicator of changes occurring in soil contaminated with heavy metals.

\section{Experimental Procedures}

\section{Scope of the Experiment}

The scope of our study included determining arylsulfatase activity in loamy sand (LS), sandy loam (SL), and sandy clay loam (SCL) subjected to contamination with $\mathrm{Zn}^{+2}, \mathrm{Cu}^{2+}, \mathrm{Ni}^{2+}, \mathrm{Cd}^{2+}$, and $\mathrm{Pb}^{2+}$. The soils were collected at the Tomaszkowo Didactic and Experimental Station of the University of Warmia and Mazury in Olsztyn (NE Poland, $53.7161^{\circ} \mathrm{N}, 20.4167^{\circ} \mathrm{E}$ ). It was assumed that the experiments would be carried out in two $\mathrm{pH}$ ranges: 7.0 and 5.5; the LS, with a $\mathrm{pH}$ of 5.5, was subjected to alkalizing with $1 \%$ aqueous suspension of $\mathrm{CaCO}_{3}$, while the SCL, with $\mathrm{pH}$ of 7.0, was acidified using a $1 \mathrm{M}$ aqueous solution of $\mathrm{HCl}$. In consequence, the desired $\mathrm{pH}$ values were obtained in these soils: LS with a $\mathrm{pH}$ of 7.0 and 5.5, SCL with a $\mathrm{pH}$ of 7.0 and 5.5. A detailed description of the soils is presented in Table 1.

\section{Conditions of the Experiment}

The experiments were carried out under laboratory conditions with the following variable factors: a) type of soil texture: loamy sand - LS, sandy loam - SL, sandy clay loam - SCL; b) pH of the soil: 5.5, 7.0; c) heavy metals used: $\mathrm{Zn}^{2+}, \mathrm{Cu}^{2+}, \mathrm{Ni}^{2+}, \mathrm{Cd}^{2+}, \mathrm{Pb}^{2+} ;$ d) level of contamination of the soil with heavy metals: $0^{\circ}, \mathrm{I}^{\circ}, \mathrm{II}^{\circ}, \mathrm{III}^{\circ}, \mathrm{IV}^{\circ}$, $\mathrm{V}^{\circ}$ (Table 2); e) incubation time of the soil: $30,60,120$ days. $100 \mathrm{~g}$ of air-dried soil was weighed out to each of a 
Table 2. Doses of heavy metals used in the experiment $(\mathrm{mg} / \mathrm{kg}$ $\mathrm{DM}$ of soil).

\begin{tabular}{|c|c|c|c|c|c|c|}
\hline \multirow{2}{*}{$\begin{array}{c}\text { Heavy } \\
\text { metal }\end{array}$} & \multicolumn{6}{|c|}{ Soil contamination degree } \\
\cline { 2 - 7 } & $0^{\circ}$ & $\mathrm{I}^{\circ}$ & $\mathrm{II}^{\circ}$ & $\mathrm{III}^{\circ}$ & $\mathrm{IV}^{\circ}$ & $\mathrm{V}^{\circ}$ \\
\hline $\mathrm{Zn}^{2+}$ & 0 & 70 & 200 & 500 & 1500 & 5000 \\
\hline $\mathrm{Cu}^{2+}$ & 0 & 25 & 50 & 80 & 100 & 500 \\
\hline $\mathrm{Ni}^{2+}$ & 0 & 25 & 50 & 75 & 150 & 600 \\
\hline $\mathrm{Cd}^{2+}$ & 0 & 0.5 & 1.5 & 3 & 5 & 10 \\
\hline $\mathrm{Pb}^{2+}$ & 0 & 50 & 100 & 250 & 1000 & 5000 \\
\hline
\end{tabular}

series of $100 \mathrm{~cm}^{3}$ beakers, then the soil was contaminated with aqueous solutions of: $\mathrm{ZnCl}_{2}, \mathrm{CuCl}_{2}, \mathrm{NiCl}_{2} \cdot 6 \mathrm{H}_{2} \mathrm{O}$, $\mathrm{CdCl}_{2} \cdot 2 \frac{1}{2} \mathrm{H}_{2} \mathrm{O}$, and $\mathrm{PbCl}_{2}$. For the sake of diversified toxicity of heavy metals, their permissible concentrations are various, and therefore the doses of the metals (Table 2) were defined based on the grades of soil usability for agricultural and non-agricultural purposes valid in Poland and developed by the Institute of Soil Science and Plant Cultivation in Puławy, Poland [22].

Detailed characteristics of the levels of contamination of the soil with heavy metals are presented by Wieczorek et al. [23]. Soil thoroughly mixed with the solution of heavy metals was brought to $50 \%$ of maximum water capacity, protected with plastic film, and placed in an incubator with a constant temperature of $25^{\circ} \mathrm{C}$. During the whole duration of the experiment (120 days) the humidity level of the soil was checked weekly and water losses were complemented. After 30,60 , and 120 days, a part of the experiment was liquidated and the activity of arylsulfatase was determined. The experiment was carried out in nine repetitions.

\section{Determination of Arylsulfatase Activity}

The activity of arylsulfatase (EC 3.1.6.1) was determined according to Alef et al. [24]. Two $\mathrm{g}$ of the soil was weighed out to each of a series of $100 \mathrm{~cm}^{3}$ conical flasks, and $4 \mathrm{~cm}^{3}$ of acetate buffer with a $\mathrm{pH}$ of 5.8 was added. Then, $1 \mathrm{~cm}^{3}$ of $0.02 \mathrm{M}$ potassium 4-nitrophenylsulfate (PNS) was added to each of the tested samples, and they were incubated for 1 hour at $37^{\circ} \mathrm{C}$. After the incubation, $1 \mathrm{~cm}^{3}$ of $0.02 \mathrm{M}$ PNS was added to the standard samples, then $25 \mathrm{~cm}^{3}$ of deionised water was added to every sample, and the suspension was filtered through hardened quantitative filter paper into $100 \mathrm{~cm}^{3}$ conical flasks. Then, $6 \mathrm{~cm}^{3}$ of the filtrate was collected to $20 \mathrm{~cm}^{3}$ test tubes and $4 \mathrm{~cm}^{3}$ of $0.5 \mathrm{M} \mathrm{NaOH}$ solution was added. Extinction of the filtrate was measured using a Perkin-Elmer Lambda 25 spectrophotometer $(\lambda=420 \mathrm{~nm})$. The activity of arylsulfatase was reported as $\mathrm{mM}$ of 4-nitrophenol (PNP) obtained during 1 hour in $1 \mathrm{~kg}$ DM of soil.
Calculation of the Resistance Index of Arylsulfatase to Heavy Metals (RS)

Based on the activity of arylsulfatase, a resistance index of the enzyme (RS) to contamination with heavy metals was calculated. The following formula was used for the calculations [25]:

$$
\mathrm{RS}=1-\frac{2\left|\mathrm{D}_{0}\right|}{\mathrm{C}_{0}+\left|\mathrm{D}_{0}\right|}
$$

...where $\mathrm{C}_{0}$ is activity of arylsulfatase in the soil with natural contents of heavy metals, and $\mathrm{D}_{0}$ is the difference between the activity of arylsulfatase in the soil with natural contents of heavy metals (and that in soil subjected to pressure of heavy metals for 30 days). The RS coefficient can range from -1 to +1 . Value +1 means that there is no disturbance (full resistance). Lower values indicate a bigger influence of a balance-disturbing factor (lower resistance). Resistance index equal to 0 indicates $100 \%$ disturbance, while negative values show a disturbance manifesting itself by an increase in resistance in comparison to a non-contaminated object.

\section{Determination of Physico-Chemical Properties of Soils}

Granulometric composition of the soils was determined by densitometry using the Cassagrande method modified by Prószyński; hydrolytic acidity (HAC) of the soils and total exchangeable basic cations (TEB) were determined according to the Kappen method [26]; organic carbon content $\left(\mathrm{C}_{\text {org }}\right)$ was determined using the Tiurin method [27]; $\mathrm{pH}$ of the soils was determined by potentiometry, in a $1 \mathrm{M} \mathrm{KCl}$ suspension in a ratio of 2.5:1 to the soil [28]. Based on the HAC and TEB values, cation exchange capacity of the soils (CEC) and the degree of saturation of the soils with basic cations (BS) were calculated.

\section{Determination of Heavy Metal Contents in the Soil}

Determination of the heavy metal contents in soils was carried out using an AAS-30 apparatus from Carl Zeiss Jena, after extraction with a $1 \mathrm{M}$ solution of hydrochloric acid $[29,30]$. The contents of metals were determined at the following wavelengths: $214 \mathrm{~nm}$ for zinc, $328 \mathrm{~nm}$ for copper, $232 \mathrm{~nm}$ of nickel, $228 \mathrm{~nm}$ for cadmium, and 284 $\mathrm{nm}$ for lead (Table 3).

\section{Statistical Calculations}

The data were processed statistically using the ANOVA variance analysis module [31]. By carrying out Tukey's test at the significance level of $p=0.01$, homogeneous groups were defined. Pearson linear correlation coefficients between the arylsulfatase activity and RS index, and the degrees of contamination of the soil with heavy metals were calculated. 
Table 3. Measured concentrations of available content of heavy metals ( $\mathrm{mg} / \mathrm{kg} \mathrm{DM}$ of soil).

\begin{tabular}{|c|c|c|c|c|c|c|c|c|}
\hline \multirow{3}{*}{ Heavy metal } & \multirow{3}{*}{ Soil type ${ }^{2}$} & \multirow{3}{*}{$\mathrm{pH}$} & \multicolumn{6}{|c|}{ Soil contamination degree ${ }^{1}$} \\
\hline & & & $0^{\circ}$ & $\mathrm{I}^{\circ}$ & II $^{\circ}$ & III $^{\circ}$ & $\mathrm{IV}^{\circ}$ & $\mathrm{V}^{\circ}$ \\
\hline & & & \multicolumn{6}{|c|}{$\mathrm{mg} / \mathrm{kg} \mathrm{DM}$ of soil } \\
\hline \multirow{6}{*}{$\mathrm{Zn}^{2+}$} & \multirow{2}{*}{ LS } & 7.0 & 10.8 & 79.5 & 208.4 & 503.2 & 1450.3 & 4916.7 \\
\hline & & 5.5 & 10.8 & 81.2 & 212.6 & 513.3 & 1479.3 & 5015.0 \\
\hline & \multirow{2}{*}{ SL } & 7.0 & 16.6 & 81.7 & 209.0 & 504.1 & 1461.2 & 4920.6 \\
\hline & & 5.5 & 11.6 & 80.9 & 213.2 & 515.4 & 1485.6 & 5020.0 \\
\hline & \multirow{2}{*}{ SCL } & 7.0 & 13.0 & 82.8 & 213.8 & 503.2 & 1460.1 & 4921.5 \\
\hline & & 5.5 & 13.0 & 82.8 & 214.3 & 515.0 & 1484.3 & 5019.8 \\
\hline \multirow{6}{*}{$\mathrm{Cu}^{2+}$} & \multirow{2}{*}{ LS } & 7.0 & 2.5 & 24.5 & 44.8 & 74.1 & 87.7 & 473.5 \\
\hline & & 5.5 & 2.5 & 24.9 & 45.9 & 77.3 & 93.4 & 487.9 \\
\hline & \multirow{2}{*}{ SL } & 7.0 & 3.8 & 25.8 & 46.1 & 75.4 & 89.0 & 474.8 \\
\hline & & 5.5 & 1.2 & 26.2 & 47.2 & 78.6 & 94.7 & 489.2 \\
\hline & \multirow{2}{*}{ SCL } & 7.0 & 3.6 & 25.6 & 45.9 & 75.2 & 88.8 & 474.6 \\
\hline & & 5.5 & 3.6 & 25.4 & 45.7 & 75.0 & 88.6 & 474.4 \\
\hline \multirow{6}{*}{$\mathrm{Ni}^{2+}$} & \multirow{2}{*}{ LS } & 7.0 & 3.2 & 23.4 & 44.6 & 69.8 & 140.0 & 524.4 \\
\hline & & 5.5 & 3.2 & 24.3 & 46.8 & 71.2 & 151.2 & 567.6 \\
\hline & \multirow{2}{*}{ SL } & 7.0 & 4.6 & 24.6 & 45.8 & 71.0 & 141.2 & 525.6 \\
\hline & & 5.5 & 4.5 & 25.4 & 47.9 & 72.3 & 152.3 & 568.7 \\
\hline & \multirow{2}{*}{ SCL } & 7.0 & 3.7 & 24.1 & 45.3 & 70.5 & 140.7 & 525.1 \\
\hline & & 5.5 & 3.7 & 24.8 & 47.3 & 71.7 & 151.7 & 568.1 \\
\hline \multirow{6}{*}{$\mathrm{Cd}^{2+}$} & \multirow{2}{*}{ LS } & 7.0 & 0.3 & 0.8 & 1.6 & 3.3 & 5.2 & 10.0 \\
\hline & & 5.5 & 0.3 & 0.8 & 1.7 & 3.4 & 5.3 & 10.2 \\
\hline & CI & 7.0 & 0.3 & 0.8 & 1.7 & 3.2 & 5.3 & 10.4 \\
\hline & & 5.5 & 1.0 & 1.4 & 2.6 & 4.3 & 6.4 & 11.3 \\
\hline & CCI & 7.0 & 0.2 & 0.7 & 1.6 & 3.1 & 5.2 & 10.3 \\
\hline & & 5.5 & 0.2 & 0.8 & 1.7 & 3.2 & 5.2 & 10.4 \\
\hline \multirow{6}{*}{$\mathrm{Pb}^{2+}$} & \multirow{2}{*}{ LS } & 7.0 & 12.0 & 55.7 & 108.3 & 247.2 & 953.6 & 4921.0 \\
\hline & & 5.5 & 12.0 & 59.6 & 112.3 & 255.8 & 983.5 & 4978.5 \\
\hline & \multirow{2}{*}{ SL } & 7.0 & 16.0 & 59.2 & 111.8 & 250.7 & 957.1 & 4924.5 \\
\hline & & 5.5 & 9.3 & 62.8 & 114.5 & 259.0 & 986.7 & 4981.7 \\
\hline & \multirow{2}{*}{ SCL } & 7.0 & 11.9 & 63.4 & 114.0 & 254.9 & 961.3 & 4928.7 \\
\hline & & 5.5 & 11.9 & 65.3 & 114.9 & 259.8 & 997.2 & 4995.1 \\
\hline
\end{tabular}

${ }^{1} 0^{\circ}$ - natural content, $\mathrm{I}^{\circ}$ - elevated content, $\mathrm{II}^{\circ}$ - weak contamination, $\mathrm{III}^{\circ}$ - medium contamination, $\mathrm{IV}^{\circ}$ - strong contamination, $\mathrm{V}^{\circ}$ - very strong contamination $\quad{ }^{2} \mathrm{LS}$ - loamy sand, $\mathrm{SL}$ - sandy loam, $\mathrm{SCL}$ - sandy clay loam

The activity and resistance of arylsulfatase to contamination of the soil with heavy metals were also presented in the form of graphs of primary component analysis (PCA). Based on the analysis of the effect measure $\eta^{2}$ by variance analysis (ANOVA) percentage shares of all variable factors affecting the activity of arylsulfatase were defined.

\section{Results}

\section{Activity of Arylsulfatase}

In the paper the results for arylsulfatase activity were shown in the form of average values of the three experiment dates, because the $\eta^{2}$ variance analysis indicated that the 
Table 4. The analysis of the effect measure $\eta^{2}$ in soils contaminated with $\mathrm{Zn}^{2+}, \mathrm{Cu}^{2+}, \mathrm{Ni}^{2+}, \mathrm{Cd}^{2+}$, and $\mathrm{Pb}^{2+}$.

\begin{tabular}{|c|c|c|c|c|c|}
\hline \multirow{2}{*}{ Factor $^{1}$} & $\mathrm{Zn}^{2+}$ & $\mathrm{Cu}^{2+}$ & $\mathrm{Ni}^{2+}$ & $\mathrm{Cd}^{2+}$ & $\mathrm{Pb}^{2+}$ \\
\hline & \multicolumn{5}{|c|}{ [\%] } \\
\hline $\mathrm{a}$ & 5.54 & 3.57 & 4.08 & 1.65 & 13.97 \\
\hline $\mathrm{b}$ & 41.52 & 51.42 & 30.37 & 25.58 & 5.55 \\
\hline $\mathrm{c}$ & 2.59 & 1.75 & 11.31 & 13.56 & 3.87 \\
\hline d & 7.25 & 2.64 & 3.22 & 0.77 & 10.26 \\
\hline$a b$ & 1.72 & 1.48 & 4.30 & 4.28 & 30.67 \\
\hline $\mathrm{ac}$ & 0.03 & 0.21 & 0.25 & 0.52 & 0.47 \\
\hline bc & 3.77 & 2.00 & 17.59 & 16.53 & 4.49 \\
\hline ad & 0.78 & 0.31 & 0.21 & 0.60 & 4.65 \\
\hline bd & 15.05 & 7.02 & 9.06 & 10.71 & 2.11 \\
\hline $\mathrm{cd}$ & 6.32 & 8.62 & 5.21 & 6.93 & 1.43 \\
\hline$a b c$ & 0.31 & 0.65 & 0.52 & 0.46 & 1.31 \\
\hline abd & 1.22 & 1.39 & 0.53 & 0.40 & 5.85 \\
\hline acd & 0.35 & 0.87 & 0.45 & 0.27 & 3.54 \\
\hline bcd & 12.37 & 17.15 & 11.30 & 15.45 & 1.24 \\
\hline abcd & 0.80 & 0.69 & 1.31 & 1.28 & 9.98 \\
\hline Error & 0.38 & 0.24 & 0.29 & 1.02 & 0.62 \\
\hline
\end{tabular}

a - soil contamination degree, $\mathrm{b}$ - soil type, $\mathrm{c}$ - soil $\mathrm{pH}$, $\mathrm{d}$ - soil incubation period

duration of incubation of the soil affected the activity of the enzyme to the least degree (from 0.77 to $10.26 \%$ ). The following factors affected the activity of the enzyme to higher degrees: the value of $\mathrm{pH}$ of the soil (from 1.75 to $13.56 \%$ ), the type of soil texture (from 5.55 to $51.42 \%$ ), and the degree of contamination of the soil with the heavy metal (from 1.65 to $13.97 \%$ ) (Table 4).

The activity of arylsulfatase was the highest in SCL, next in SL, and the lowest in LS in uncontaminated soils, probably due to differences in organic carbon and exchangeable basic cations content and sorption capacity of soil. An increase of arylsulfatase activity was observed with the increasing value of these physicochemical parameters.

In the SCL with a $\mathrm{pH}$ of 7.0, a significantly higher activity of arylsulfatase was observed than in the other soils. In the SL with a $\mathrm{pH}$ of 7.0, the activity was twice as high as in the SL with a pH of 5.5, while the situation was opposite in the case of LS with a $\mathrm{pH}$ of 7.0 and LS with a $\mathrm{pH}$ of 5.5 (Table 5 ).

In the $\mathrm{LS}$ with a $\mathrm{pH}$ of $7.0, \mathrm{Zn}^{2+}$ inhibited the activity of arylsulfatase in the range from 11 to $77 \%, \mathrm{Cu}^{2+}-$ from 15 to $62 \%, \mathrm{Ni}^{2+}$ - from 9 to $26 \%$, and $\mathrm{Cd}^{2+}-$ from 12 to $26 \%$. Contamination with $\mathrm{Pb}^{2+}$ did not reduce arylsulfatase activity, but on the contrary increased it. A $\mathrm{I}^{\circ}$ contamination of the soil with this element caused a $300 \%$ increase in the arylsulfatase activity in comparison to the soil with a natural $\mathrm{Pb}^{2+}$ content, $\mathrm{II}^{\circ}-\mathrm{IV}^{\circ}$ a $98 \%$ increase, and $\mathrm{VI}^{\circ}$ a $65 \%$ increase. The effect of $\mathrm{Zn}^{2+}$ and $\mathrm{Cu}^{2+}$ in the LS with a $\mathrm{pH}$ of 5.5 contributed to a decrease of arylsulfatase activity in the range from 31 to $94 \%$ and from 22 to $74 \%$, respectively. Contamination with $\mathrm{Pb}^{2+}$ did not affect the activity of the enzyme unequivocally adversely, as the pollutant amount of $50 \mathrm{mg} / \mathrm{kg} \mathrm{DM}$ of soil led to an increase in the arylsulfatase activity by $12 \%$, and doses of $5,000 \mathrm{mg} / \mathrm{kg}$ DM of soil contributed to a $13 \%$ decrease in enzyme activity. At $\mathrm{I}^{\circ}$ of contamination in the LS with a $\mathrm{pH}$ of 5.5, the effect of $\mathrm{Ni}^{2+}$ was more unfavourable than in the LS with a $\mathrm{pH}$ of 7.0. Higher doses of this metal decreased the arylsulfatase activity in the LS with a $\mathrm{pH}$ of 5.5 more than in the LS with a pH of 7.0. The effect of $\mathrm{Cd}^{2+}$ was significantly weaker in the LS with a $\mathrm{pH}$ of 5.5 than in the LS with a $\mathrm{pH}$ of 7.0, in which arylsulfatase activity was limited to $2-10 \%$ compared to $0^{\circ}$.

Arylsulfatase activity decreased in the SL with a $\mathrm{pH}$ of 7.0: from $36\left(\mathrm{I}^{\circ}\right)$ to $93 \%\left(\mathrm{~V}^{\circ}\right)$ in the case of $\mathrm{Zn}^{2+}$, and from $23\left(\mathrm{I}^{\circ}\right)$ to $35 \%\left(\mathrm{~V}^{\circ}\right)$ in the case of $\mathrm{Pb}^{2+}$ (in comparison with the non-contaminated soil). Doses of $25 \mathrm{mg} \mathrm{Cu}^{2+}$ and 25 $\mathrm{mg} \mathrm{Ni}^{2+} / \mathrm{kg}$ DM of soil led to an increase in enzyme activity by $19 \%$ and $15 \%$, respectively. Higher doses of $\mathrm{Cu}^{2+}$ and $\mathrm{Ni}^{2+}$ acted adversely - at $\mathrm{V}^{\mathrm{o}}$ they decreased arylsulfatase activity to $72 \%$ and $25 \%$, respectively. $\mathrm{Cd}^{2+}$ had a more inverse effect than $\mathrm{Zn}^{2+}$ and $\mathrm{Pb}^{2+}$, irrespective of its dose. A dose of $0.5 \mathrm{mg} / \mathrm{kg} \mathrm{DM}$ of soil contributed to an increase of enzyme activity by $57 \%$, and the highest dose $20 \mathrm{mg} / \mathrm{kg}$ DM of soil - by $15 \%$ in comparison to soil with a natural amount of $\mathrm{Cd}^{2+}$. In spite of this, arylsulfatase activity decreased together with an increase in the degree of contamination of the soil with this element.

The influence of $\mathrm{pH}$ of the soil affected the activity of arylsulfatase more clearly in the SL contaminated with $\mathrm{Ni}^{2+}$ and $\mathrm{Cd}^{2+}$, where the presence of these metals in the SL with a $\mathrm{pH}$ of 5.5 adversely influenced the arylsulfatase activity to a larger extent. The value of the $\mathrm{pH}$ of the soil affected the activity of the enzyme in the SL contaminated with $\mathrm{Zn}^{2+}, \mathrm{Cu}^{2+}$, and $\mathrm{Pb}^{2+}$ to a smaller extent than the degree of contamination of the soil with these elements.

The introduction of $\mathrm{Zn}^{2+}, \mathrm{Ni}^{2+}, \mathrm{Cd}^{2+}$, and $\mathrm{Pb}^{2+}$ to the SCL with a pH of 5.5 disturbed the action of arylsulfatase to a larger extent than their introduction to the SCL with a $\mathrm{pH}$ of 5.5. The activity of the enzyme decreased most greatly under the influence of contamination with $\mathrm{Cd}^{2+}$ and $\mathrm{Pb}^{2+}$. Contamination of soil with $\mathrm{Cd}^{2+}$ and $\mathrm{Pb}^{2+}$ above $\mathrm{I}^{\circ}$ decreased the arylsulfatase activity only slightly. In the case of $\mathrm{Cu}^{2+}$, the response of the enzyme depended most strongly on the dose of the metal. $\mathrm{I}^{\circ}$ and $\mathrm{II}^{\circ}$ of contamination with $\mathrm{Cu}^{2+}$ increased the arylsulfatase activity in the SCL with a $\mathrm{pH}$ of 5.5 , while contents below $50 \mathrm{mg} / \mathrm{kg} \mathrm{DM}$ of soil decreased it more than in the SCL with a $\mathrm{pH}$ of 7.0. The effect of $\mathrm{Zn}^{2+}, \mathrm{Ni}^{2+}$, and $\mathrm{Pb}^{2+}$ was significantly stronger in the acidified soil, while the decrease in the arylsulfatase activity by contamination with $\mathrm{Pb}^{2+}$ was only slightly smaller in the SCL with a pH of 7.0 than in the SCL with a $\mathrm{pH}$ of 5.5 .

As results from Fig. 1 show, primary components explain $93.34 \%$ of the original variables. These variables 


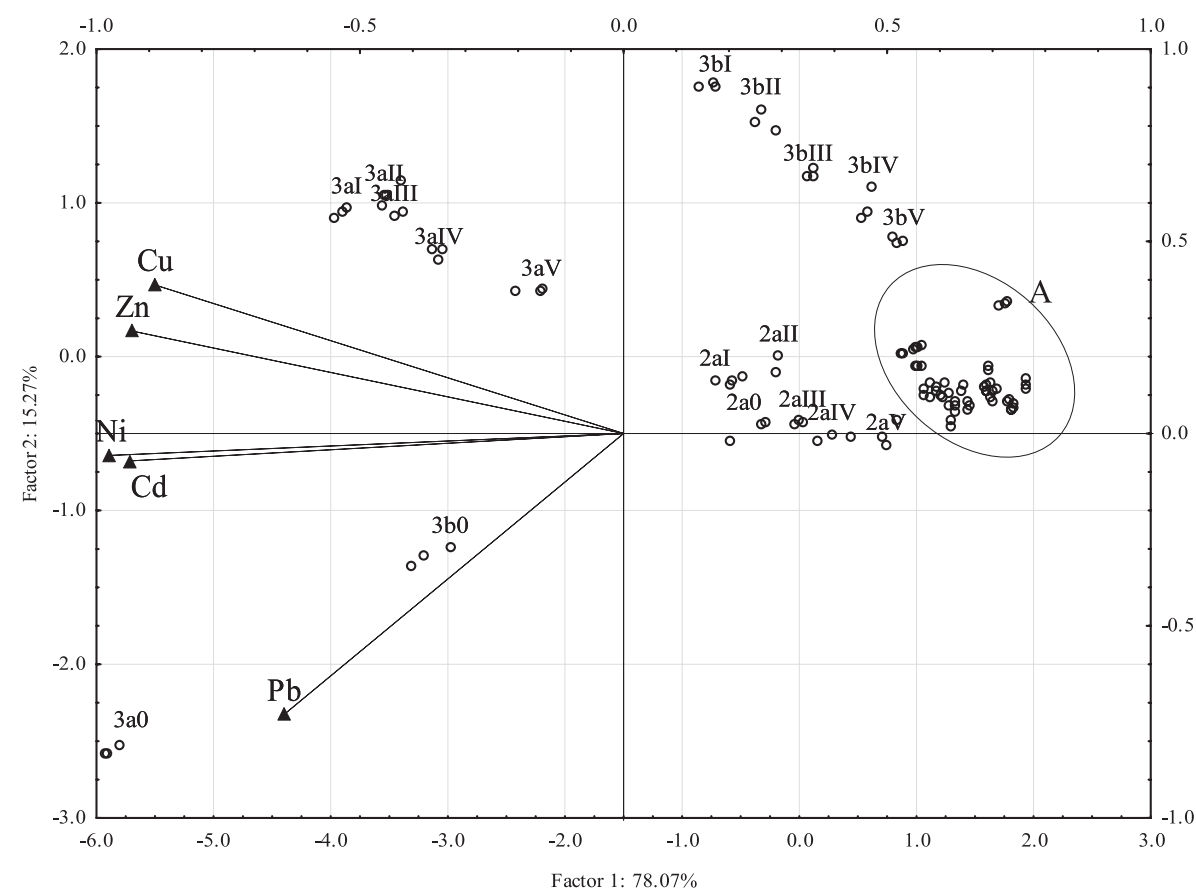

Fig. 1. Arylsulfatase activity in soils contaminated with $\mathrm{Zn}^{2+}, \mathrm{Cu}^{2+}, \mathrm{Ni2} 2^{+}, \mathrm{Cd}^{2+}$, and $\mathrm{Pb}^{2+}$, presented with principal component analysis.

soil type: 1 - loamy sand, 2 - sandy loam, 3 - sandy clay loam; soil pH: a - pH 7.0, b - pH 5.5; soil contamination degree: 0 - $0^{\circ}$, I - $\mathrm{I}^{\circ}$, II - II', III - III', IV - IV, V - V

A: $1 \mathrm{a} 0-1 \mathrm{aV}, 1 \mathrm{~b} 0-1 \mathrm{bV}, 2 \mathrm{~b} 0-2 \mathrm{bV}$

are negatively correlated with the first primary component. The strongest positive correlation was found between the degrees of soil contamination with $\mathrm{Ni}^{2+}$ and $\mathrm{Cd}^{2+}$, with a slightly weaker correlation between soil contamination with $\mathrm{Zn}^{2+}$ and $\mathrm{Cu}^{2+}$. A different effect on the activity of arylsulfatase was found between $\mathrm{Cu}^{2+}$ and $\mathrm{Pb}^{2+}$ and between $\mathrm{Zn}^{2+}$ and $\mathrm{Pb}^{2+}$. The influence of heavy metals on the arylsulfatase activity was the highest in the SCL with a $\mathrm{pH}$ of 7.0, then in the SCL with a $\mathrm{pH}$ of 5.5, SL with a $\mathrm{pH}$ of 7.0, SL with a $\mathrm{pH}$ of 5.5 , LS with a $\mathrm{pH}$ of 5.5; the smallest was in the LS with a $\mathrm{pH}$ of 7.0.

\section{RS Index}

Arylsulfatase exhibited a higher resistance in the LS with a $\mathrm{pH}$ of 7.0 contaminated with $\mathrm{Zn}^{2+}, \mathrm{Cu}^{2+}$, and $\mathrm{Ni}^{2+}$, while a higher resistance of the enzyme was found under the influence of contamination with $\mathrm{Cd}^{2+}$ and $\mathrm{Pb}^{2+}$ in the LS with a pH of 5.5 (Table 6). Contamination with $\mathrm{Ni}^{2+}$ did not significantly affect the resistance of arylsulfatase in the LS with a $\mathrm{pH}$ of 7.0, while resistance increased in the case of contamination of the same soil with $\mathrm{Pb}^{2+}$.

In the SL, the resistance of arylsulfatase was more diversified. An acidic reaction decreased the resistance of arylsulfatase more strongly in the soil contaminated with $\mathrm{Cd}^{2+}$ and $\mathrm{Pb}^{2+}$, with a neutral reaction in the soil contaminated with $\mathrm{Zn}^{2+}$ and $\mathrm{Cu}^{2+}$. Acidification of the SL contaminated with $\mathrm{Ni}^{2+}$ in doses of 25 and $600 \mathrm{mg} / \mathrm{kg} \mathrm{DM}$ of soil affected arylsulfatase resistance more adversely than on the SL with a $\mathrm{pH}$ of 7.0.
Irrespective of the doses of $\mathrm{Ni}^{2+}, \mathrm{Cd}^{2+}$, and $\mathrm{Pb}^{2+}$, the resistance of arylsulfatase was by $75-91 \%$ lower in the SCL with a $\mathrm{pH}$ of 5.5 than the resistance in the noncontaminated soil. Increasing the doses of these metals did not increase the resistance of the enzyme significantly in comparison with $\mathrm{I}^{\circ}$. In the SCL with a $\mathrm{pH}$ of 7.0, these metals did not exhibit such a high reduction of the RS index in relation to the non-contaminated sample (from 8 to $38 \%$ ). Contamination of SCL with a $\mathrm{pH}$ of 5.5 using $\mathrm{Zn}^{2+}$ in the amount of $70 \mathrm{mg} / \mathrm{kg}$ and $\mathrm{Cu}^{2+}$ in a dose of $25 \mathrm{mg} / \mathrm{kg} \mathrm{DM}$ of soil caused a significant disturbance of the arylsulfatase resistance (52\% and $82 \%$ decrease, respectively). The introduction of these metals corresponding to degrees $\mathrm{II}^{\circ}$ $\mathrm{IV}^{\circ}$ did not reduce the resistance to such a large extent. Irrespective of the $\mathrm{pH}$ of the soil, contamination of the SCL with $\mathrm{Zn}^{2+}$ from $\mathrm{II}^{\circ}$ to $\mathrm{V}^{\circ}$ led to a gradual decrease in the resistance of arylsulfatase, while the same was obvious in the case of contamination with $\mathrm{Cu}^{2+}$ only at $\mathrm{V}^{\circ}$.

As results from Fig. 2 show, primary components explain $71.95 \%$ of the original variables. In the same soils, $\mathrm{Ni}^{2+}, \mathrm{Cd}^{2+}$, and $\mathrm{Pb}^{2+}$ affected the resistance of arylsulfatase similarly. On the other hand, a different influence on the resistance of arylsulfatase was found in the soil contaminated with $\mathrm{Zn}^{2+}$. No correlation between $\mathrm{Cu}^{2+}$ and $\mathrm{Ni}^{2+}, \mathrm{Cd}^{2+}$ and $\mathrm{Pb}^{2+}$, and $\mathrm{Zn}^{2+}$ and $\mathrm{Cu}^{2+}$ was proven. The resistance of arylsulfatase was reduced most strongly by contamination with $\mathrm{Cu}^{2+}$, then by $\mathrm{Cd}^{2+}, \mathrm{Ni}^{2+}$, and $\mathrm{Zn}^{2+}$, and most weakly by $\mathrm{Pb}^{2+}$. Also, a stronger influence of heavy metals on arylsulfatase resistance was found in acidic soils than in neutral soils, particularly in the SCL with a $\mathrm{pH}$ of 7.0. 
Table 5. Activity of soil arylsulfatase in soils contaminated with $\mathrm{Zn}^{2+}, \mathrm{Cu}^{2+}, \mathrm{Ni}^{2+}, \mathrm{Cd}^{2+}$, and $\mathrm{Pb}^{2+}(\mathrm{mM} \mathrm{PNP} / \mathrm{kg} / \mathrm{h} \mathrm{DM}$ of soil).

\begin{tabular}{|c|c|c|c|c|c|c|c|c|}
\hline \multirow{2}{*}{ Soil type ${ }^{2}$} & \multirow{2}{*}{ Soil pH } & \multicolumn{6}{|c|}{ Soil contamination degree ${ }^{1}$} & \multirow{2}{*}{$\mathrm{r}^{3}$} \\
\hline & & $0^{\circ}$ & $\mathrm{I}^{\circ}$ & $\mathrm{II}^{\circ}$ & $\mathrm{III}^{\circ}$ & $\mathrm{IV}^{\circ}$ & $\mathrm{V}^{\circ}$ & \\
\hline \multicolumn{9}{|c|}{$\mathrm{Zn}^{2+}$} \\
\hline \multirow{2}{*}{ LS } & 7.0 & $0.130^{\mathrm{a}}$ & $0.116^{\mathrm{b}}$ & $0.114^{\mathrm{b}}$ & $0.063^{\mathrm{c}}$ & $0.043^{\mathrm{d}}$ & $0.030^{\mathrm{e}}$ & $-0.840^{* *}$ \\
\hline & 5.5 & $0.241^{\mathrm{a}}$ & $0.167^{\mathrm{b}}$ & $0.114^{\mathrm{c}}$ & $0.066^{\mathrm{d}}$ & $0.025^{\mathrm{e}}$ & $0.015^{\mathrm{e}}$ & $-0.896^{* *}$ \\
\hline \multirow{2}{*}{ SL } & 7.0 & $0.417^{\mathrm{a}}$ & $0.267^{\mathrm{b}}$ & $0.232^{\mathrm{b}}$ & $0.157^{\mathrm{c}}$ & $0.043^{\mathrm{d}}$ & $0.031^{\mathrm{d}}$ & $-0.912^{* *}$ \\
\hline & 5.5 & $0.228^{\mathrm{a}}$ & $0.173^{\mathrm{b}}$ & $0.133^{\mathrm{c}}$ & $0.077^{\mathrm{d}}$ & $0.040^{\mathrm{e}}$ & $0.037^{\mathrm{e}}$ & $-0.940^{* *}$ \\
\hline \multirow{2}{*}{ SCL } & 7.0 & $1.151^{\mathrm{ab}}$ & $1.158^{\mathrm{a}}$ & $1.093^{\mathrm{bc}}$ & $1.081^{\mathrm{c}}$ & $0.851^{\mathrm{d}}$ & $0.663^{\mathrm{e}}$ & -0.212 \\
\hline & 5.5 & $0.840^{\mathrm{a}}$ & $0.691^{\mathrm{bc}}$ & $0.731^{\mathrm{b}}$ & $0.628^{c}$ & $0.362^{\mathrm{d}}$ & $0.225^{\mathrm{e}}$ & $-0.606^{* *}$ \\
\hline \multicolumn{9}{|c|}{$\mathrm{Cu}^{2+}$} \\
\hline \multirow{2}{*}{ LS } & 7.0 & $0.130^{\mathrm{a}}$ & $0.110^{\mathrm{a}}$ & $0.099^{\mathrm{ab}}$ & $0.073^{\mathrm{bc}}$ & $0.071^{\mathrm{bc}}$ & $0.050^{\mathrm{c}}$ & $-0.717^{* *}$ \\
\hline & 5.5 & $0.241^{\mathrm{a}}$ & $0.187^{\mathrm{b}}$ & $0.169^{\mathrm{b}}$ & $0.135^{\mathrm{c}}$ & $0.122^{\mathrm{c}}$ & $0.062^{\mathrm{d}}$ & $-0.855^{* *}$ \\
\hline \multirow{2}{*}{ SL } & 7.0 & $0.417^{\mathrm{b}}$ & $0.497^{\mathrm{a}}$ & $0.484^{\mathrm{a}}$ & $0.374^{b}$ & $0.317^{\mathrm{c}}$ & $0.118^{\mathrm{d}}$ & $-0.594^{* *}$ \\
\hline & 5.5 & $0.228^{\mathrm{a}}$ & $0.226^{\mathrm{a}}$ & $0.192^{\mathrm{b}}$ & $0.173^{\mathrm{bc}}$ & $0.163^{\mathrm{c}}$ & $0.131^{\mathrm{d}}$ & $-0.634^{* *}$ \\
\hline \multirow{2}{*}{ SCL } & 7.0 & $1.151^{\mathrm{b}}$ & $1.270^{\mathrm{a}}$ & $1.147^{\mathrm{b}}$ & $1.092^{\mathrm{b}}$ & $1.072^{\mathrm{b}}$ & $0.780^{\mathrm{c}}$ & -0.174 \\
\hline & 5.5 & $0.840^{\mathrm{b}}$ & $1.230^{\mathrm{a}}$ & $0.862^{\mathrm{b}}$ & $0.734^{c}$ & $0.670^{\mathrm{c}}$ & $0.578^{\mathrm{d}}$ & $-0.412^{* *}$ \\
\hline \multicolumn{9}{|c|}{$\mathrm{Ni}^{2+}$} \\
\hline \multirow{2}{*}{ LS } & 7.0 & $0.130^{\mathrm{a}}$ & $0.118^{\mathrm{ab}}$ & $0.105^{\mathrm{bc}}$ & $0.100^{c}$ & $0.095^{\mathrm{c}}$ & $0.096^{\mathrm{c}}$ & $-0.465^{* *}$ \\
\hline & 5.5 & $0.241^{\mathrm{a}}$ & $0.212^{\mathrm{b}}$ & $0.211^{\mathrm{bc}}$ & $0.196^{\mathrm{bcd}}$ & $0.192^{\mathrm{cd}}$ & $0.190^{\mathrm{d}}$ & $-0.397^{* *}$ \\
\hline \multirow{2}{*}{ SL } & 7.0 & $0.417^{\mathrm{b}}$ & $0.481^{\mathrm{a}}$ & $0.386^{\mathrm{bc}}$ & $0.361^{\mathrm{cd}}$ & $0.334^{\mathrm{de}}$ & $0.313^{\mathrm{e}}$ & $-0.529^{* *}$ \\
\hline & 5.5 & $0.228^{\mathrm{a}}$ & $0.234^{\mathrm{a}}$ & $0.202^{\mathrm{b}}$ & $0.185^{\mathrm{b}}$ & $0.180^{\mathrm{b}}$ & $0.122^{\mathrm{c}}$ & $-0.598^{* *}$ \\
\hline \multirow{2}{*}{ SCL } & 7.0 & $1.151^{\mathrm{a}}$ & $0.878^{b}$ & $0.882^{\mathrm{b}}$ & $0.853^{\mathrm{b}}$ & $0.849^{b}$ & $0.759^{c}$ & -0.221 \\
\hline & 5.5 & $0.840^{\mathrm{a}}$ & $0.276^{\mathrm{b}}$ & $0.233^{\mathrm{bc}}$ & $0.181^{\mathrm{c}}$ & $0.172^{\mathrm{c}}$ & $0.200^{\mathrm{bc}}$ & $-0.662^{* *}$ \\
\hline \multicolumn{9}{|c|}{$\mathrm{Cd}^{2+}$} \\
\hline \multirow{2}{*}{ LS } & 7.0 & $0.130^{\mathrm{a}}$ & $0.114^{\mathrm{ab}}$ & $0.106^{\mathrm{bc}}$ & $0.095^{c}$ & $0.099^{\mathrm{bc}}$ & $0.096^{\mathrm{c}}$ & $-0.497^{* *}$ \\
\hline & 5.5 & $0.241^{\mathrm{a}}$ & $0.237^{\mathrm{ab}}$ & $0.218^{\mathrm{ab}}$ & $0.213^{\mathrm{b}}$ & $0.211^{\mathrm{b}}$ & $0.216^{\mathrm{ab}}$ & -0.208 \\
\hline \multirow{2}{*}{ SL } & 7.0 & $0.417^{\mathrm{b}}$ & $0.653^{\mathrm{a}}$ & $0.604^{\mathrm{a}}$ & $0.553^{\mathrm{ab}}$ & $0.541^{\mathrm{ab}}$ & $0.481^{\mathrm{ab}}$ & -0.015 \\
\hline & 5.5 & $0.228^{\mathrm{ab}}$ & $0.243^{\mathrm{a}}$ & $0.225^{\mathrm{ab}}$ & $0.216^{\mathrm{ab}}$ & $0.229^{\mathrm{ab}}$ & $0.209^{\mathrm{b}}$ & -0.079 \\
\hline \multirow{2}{*}{ SCL } & 7.0 & $1.151^{\mathrm{a}}$ & $0.913^{b}$ & $0.890^{\mathrm{b}}$ & $0.899^{\mathrm{b}}$ & $0.868^{\mathrm{b}}$ & $0.873^{\mathrm{b}}$ & -0.152 \\
\hline & 5.5 & $0.840^{\mathrm{a}}$ & $0.254^{\mathrm{bc}}$ & $0.271^{\mathrm{b}}$ & $0.207^{\mathrm{cd}}$ & $0.207^{\mathrm{cd}}$ & $0.187^{\mathrm{d}}$ & $-0.586^{* *}$ \\
\hline \multicolumn{9}{|c|}{$\mathrm{Pb}^{2+}$} \\
\hline \multirow{2}{*}{ LS } & 7.0 & $0.130^{\mathrm{c}}$ & $0.255^{\mathrm{a}}$ & $0.258^{\mathrm{a}}$ & $0.257^{\mathrm{a}}$ & $0.258^{\mathrm{a}}$ & $0.215^{\mathrm{b}}$ & 0.192 \\
\hline & 5.5 & $0.241^{\mathrm{b}}$ & $0.270^{\mathrm{ab}}$ & $0.261^{\mathrm{ab}}$ & $0.286^{\mathrm{a}}$ & $0.254^{\mathrm{b}}$ & $0.210^{c}$ & -0.062 \\
\hline \multirow{2}{*}{ SL } & 7.0 & $0.417^{\mathrm{a}}$ & $0.320^{\mathrm{bc}}$ & $0.297^{\mathrm{bc}}$ & $0.340^{\mathrm{b}}$ & $0.328^{\mathrm{b}}$ & $0.273^{\mathrm{c}}$ & $-0.348^{*}$ \\
\hline & 5.5 & $0.228^{b}$ & $0.246^{\mathrm{ab}}$ & $0.270^{\mathrm{a}}$ & $0.269^{\mathrm{a}}$ & $0.248^{\mathrm{ab}}$ & $0.216^{\mathrm{b}}$ & -0.035 \\
\hline \multirow{2}{*}{ SCL } & 7.0 & $1.151^{\mathrm{a}}$ & $0.400^{\mathrm{b}}$ & $0.335^{\text {cd }}$ & $0.325^{\mathrm{cd}}$ & $0.353^{\mathrm{bc}}$ & $0.302^{\mathrm{d}}$ & $-0.534^{* *}$ \\
\hline & 5.5 & $0.840^{\mathrm{a}}$ & $0.180^{\mathrm{b}}$ & $0.147^{\mathrm{d}}$ & $0.180^{\mathrm{b}}$ & $0.161^{\mathrm{c}}$ & $0.162^{\mathrm{c}}$ & $-0.591^{* *}$ \\
\hline
\end{tabular}

${ }^{* *}$ significant for $\mathrm{p}=0.01$, significant for $\mathrm{p}=0.05, \mathrm{n}=53$

The same letters in rows are assigned to homogenous groups $(\mathrm{p}<0.01)$

${ }^{1} 0^{\circ}$ - natural content, $\mathrm{I}^{\circ}$ - elevated content, $\mathrm{II}^{\circ}$ - weak contamination, $\mathrm{III}^{\circ}$ - medium contamination, $\mathrm{IV}^{\circ}$ - strong contamination,

$\mathrm{V}^{\circ}$ - very strong contamination

${ }^{2}$ LS - loamy sand, SL - sandy loam, SCL - sandy clay loam

${ }^{3}$ correlation coefficient between the soil contamination with heavy metal and arylsulfatase activity 
Table 6. Arylsulfatase resistance index (RS) in soils contaminated with $\mathrm{Zn}^{2+}, \mathrm{Cu}^{2+}, \mathrm{Ni}^{2+}, \mathrm{Cd}^{2+}$, and $\mathrm{Pb}^{2+}$ in 30 days of incubation.

\begin{tabular}{|c|c|c|c|c|c|c|c|}
\hline \multirow{2}{*}{ Soil type ${ }^{2}$} & \multirow{2}{*}{ Soil pH } & \multicolumn{5}{|c|}{ Soil contamination degree ${ }^{1}$} & \multirow{2}{*}{$\mathrm{r}^{3}$} \\
\hline & & $\mathrm{I}^{\circ}$ & $\mathrm{II}^{\circ}$ & $\mathrm{III}^{\circ}$ & $\mathrm{IV}^{\circ}$ & $\mathrm{V}^{\circ}$ & \\
\hline \multicolumn{8}{|c|}{$\mathrm{Zn}^{2+}$} \\
\hline \multirow{2}{*}{ LS } & 7.0 & $0.930^{\mathrm{a}}$ & $0.889^{b}$ & $0.342^{\mathrm{c}}$ & $0.211^{\mathrm{d}}$ & $0.127^{\mathrm{e}}$ & $-0.934^{* *}$ \\
\hline & 5.5 & $0.919^{\mathrm{a}}$ & $0.323^{\mathrm{b}}$ & $0.215^{\mathrm{c}}$ & $0.075^{\mathrm{d}}$ & $0.015^{\mathrm{e}}$ & $-0.903^{* *}$ \\
\hline \multirow{2}{*}{ SL } & 7.0 & $0.298^{\mathrm{a}}$ & $0.215^{\mathrm{b}}$ & $0.131^{\mathrm{c}}$ & $0.033^{\mathrm{d}}$ & $0.028^{\mathrm{d}}$ & $-0.958^{* * *}$ \\
\hline & 5.5 & $0.525^{\mathrm{a}}$ & $0.248^{b}$ & $0.241^{\mathrm{b}}$ & $0.104^{\mathrm{c}}$ & $0.089^{d}$ & $-0.893^{* *}$ \\
\hline \multirow{2}{*}{ SCL } & 7.0 & $0.864^{\mathrm{a}}$ & $0.576^{\mathrm{b}}$ & $0.450^{c}$ & $0.174^{\mathrm{d}}$ & $0.090^{\mathrm{e}}$ & $-0.978^{* *}$ \\
\hline & 5.5 & $0.476^{\mathrm{c}}$ & $0.734^{\mathrm{a}}$ & $0.669^{\mathrm{b}}$ & $0.368^{\mathrm{d}}$ & $0.144^{\mathrm{e}}$ & $-0.659^{* *}$ \\
\hline \multicolumn{8}{|c|}{$\mathrm{Cu}^{2+}$} \\
\hline \multirow{2}{*}{ LS } & 7.0 & $0.866^{\mathrm{a}}$ & $0.792^{\mathrm{b}}$ & $0.322^{\mathrm{d}}$ & $0.449^{c}$ & $0.289^{\mathrm{e}}$ & $-0.787^{* *}$ \\
\hline & 5.5 & $0.805^{\mathrm{a}}$ & $0.560^{\mathrm{b}}$ & $0.390^{c}$ & $0.348^{\mathrm{d}}$ & $0.193^{\mathrm{e}}$ & $-0.944^{* *}$ \\
\hline \multirow{2}{*}{ SL } & 7.0 & $0.451^{\mathrm{a}}$ & $0.448^{\mathrm{a}}$ & $0.388^{b}$ & $0.376^{\mathrm{b}}$ & $0.078^{c}$ & $-0.774^{* *}$ \\
\hline & 5.5 & $0.547^{\mathrm{d}}$ & $0.920^{\mathrm{a}}$ & $0.651^{\mathrm{b}}$ & $0.545^{\mathrm{d}}$ & $0.565^{\mathrm{c}}$ & -0.306 \\
\hline \multirow{2}{*}{ SCL } & 7.0 & $0.972^{\mathrm{a}}$ & $0.659^{c}$ & $0.692^{b}$ & $0.973^{\mathrm{a}}$ & $0.321^{\mathrm{d}}$ & $-0.573^{*}$ \\
\hline & 5.5 & $0.176^{\mathrm{e}}$ & $0.859^{c}$ & $0.958^{b}$ & $0.990^{\mathrm{a}}$ & $0.632^{\mathrm{d}}$ & $0.505^{*}$ \\
\hline \multicolumn{8}{|c|}{$\mathrm{Ni}^{2+}$} \\
\hline \multirow{2}{*}{ LS } & 7.0 & $0.991^{\mathrm{a}}$ & $0.702^{\mathrm{b}}$ & $0.708^{b}$ & $0.671^{\mathrm{c}}$ & $0.701^{\mathrm{b}}$ & $-0.621^{*}$ \\
\hline & 5.5 & $0.822^{\mathrm{ab}}$ & $0.816^{\mathrm{b}}$ & $0.828^{\mathrm{a}}$ & $0.833^{\mathrm{a}}$ & $0.817^{\mathrm{b}}$ & 0.133 \\
\hline \multirow{2}{*}{ SL } & 7.0 & $0.804^{\mathrm{a}}$ & $0.782^{\mathrm{b}}$ & $0.755^{\mathrm{c}}$ & $0.676^{\mathrm{d}}$ & $0.601^{\mathrm{e}}$ & -0.447 \\
\hline & 5.5 & $0.603^{\mathrm{d}}$ & $0.903^{\mathrm{b}}$ & $0.954^{\mathrm{a}}$ & $0.871^{\mathrm{c}}$ & $0.267^{\mathrm{e}}$ & -0.372 \\
\hline \multirow{2}{*}{ SCL } & 7.0 & $0.925^{\mathrm{a}}$ & $0.924^{\mathrm{a}}$ & $0.825^{\mathrm{b}}$ & $0.826^{\mathrm{b}}$ & $0.618^{c}$ & $-0.848^{* *}$ \\
\hline & 5.5 & $0.159^{\mathrm{a}}$ & $0.115^{\mathrm{b}}$ & $0.119^{b}$ & $0.095^{\mathrm{c}}$ & $0.155^{\mathrm{a}}$ & -0.136 \\
\hline \multicolumn{8}{|c|}{$\mathrm{Cd}^{2+}$} \\
\hline \multirow{2}{*}{ LS } & 7.0 & $0.898^{\mathrm{a}}$ & $0.697^{\mathrm{b}}$ & $0.573^{\mathrm{e}}$ & $0.607^{\mathrm{d}}$ & $0.623^{\mathrm{c}}$ & $-0.640^{* *}$ \\
\hline & 5.5 & $0.893^{\mathrm{c}}$ & $0.927^{\mathrm{a}}$ & $0.912^{b}$ & $0.894^{\mathrm{c}}$ & $0.839^{\mathrm{d}}$ & -0.374 \\
\hline \multirow{2}{*}{ SL } & 7.0 & $0.811^{\mathrm{d}}$ & $0.852^{\mathrm{c}}$ & $0.933^{b}$ & $0.994^{\mathrm{a}}$ & $0.941^{\mathrm{b}}$ & $0.514^{*}$ \\
\hline & 5.5 & $0.285^{\mathrm{d}}$ & $0.364^{c}$ & $0.454^{b}$ & $0.280^{\mathrm{d}}$ & $0.531^{\mathrm{a}}$ & 0.496 \\
\hline \multirow{2}{*}{ SCL } & 7.0 & $0.819^{\mathrm{a}}$ & $0.829^{\mathrm{a}}$ & $0.832^{\mathrm{a}}$ & $0.716^{\mathrm{c}}$ & $0.776^{\mathrm{b}}$ & $-0.441^{*}$ \\
\hline & 5.5 & $0.180^{\mathrm{d}}$ & $0.236^{\mathrm{b}}$ & $0.206^{\mathrm{c}}$ & $0.253^{\mathrm{a}}$ & $0.257^{\mathrm{a}}$ & $0.773^{* *}$ \\
\hline \multicolumn{8}{|c|}{$\mathrm{Pb}^{2+}$} \\
\hline \multirow{2}{*}{ LS } & 7.0 & $-0.271^{\mathrm{a}}$ & $-0.288^{b}$ & $-0.264^{\mathrm{a}}$ & $-0.310^{c}$ & $-0.317^{\mathrm{c}}$ & -0.293 \\
\hline & 5.5 & $0.161^{\mathrm{b}}$ & $0.154^{\mathrm{b}}$ & $0.105^{\mathrm{d}}$ & $0.118^{c}$ & $0.372^{\mathrm{a}}$ & 0.494 \\
\hline \multirow{2}{*}{ SL } & 7.0 & $0.638^{b}$ & $0.637^{\mathrm{b}}$ & $0.655^{\mathrm{a}}$ & $0.623^{c}$ & $0.657^{\mathrm{a}}$ & 0.116 \\
\hline & 5.5 & $0.443^{\mathrm{a}}$ & $0.334^{\mathrm{d}}$ & $0.367^{\mathrm{c}}$ & $0.367^{\mathrm{c}}$ & $0.388^{\mathrm{b}}$ & 0.001 \\
\hline \multirow{2}{*}{ SCL } & 7.0 & $0.651^{\mathrm{d}}$ & $0.729^{\mathrm{b}}$ & $0.769^{\mathrm{a}}$ & $0.758^{\mathrm{a}}$ & $0.686^{\mathrm{c}}$ & $-0.586^{*}$ \\
\hline & 5.5 & $0.133^{b}$ & $0.088^{c}$ & $0.140^{\mathrm{ab}}$ & $0.132^{\mathrm{b}}$ & $0.147^{\mathrm{a}}$ & 0.492 \\
\hline
\end{tabular}

** significant for $\mathrm{p}=0.01,{ }^{*}$ significant for $\mathrm{p}=0.05, \mathrm{n}=14$

The same letters in rows are assigned to homogenous groups $(\mathrm{p}<0.01)$

${ }^{1} 0^{\circ}$ - natural content, $\mathrm{I}^{\circ}$ - elevated content, $\mathrm{II}^{\circ}$ - weak contamination, $\mathrm{III}^{\circ}$ - medium contamination, $\mathrm{IV}^{\circ}$ - strong contamination,

$\mathrm{V}^{\circ}$ - very strong contamination

${ }^{2} \mathrm{LS}$ - loamy sand, SL - sandy loam, SCL - sandy clay loam

${ }^{3}$ correlation coefficient between the soil contamination with heavy metal and resistance index 


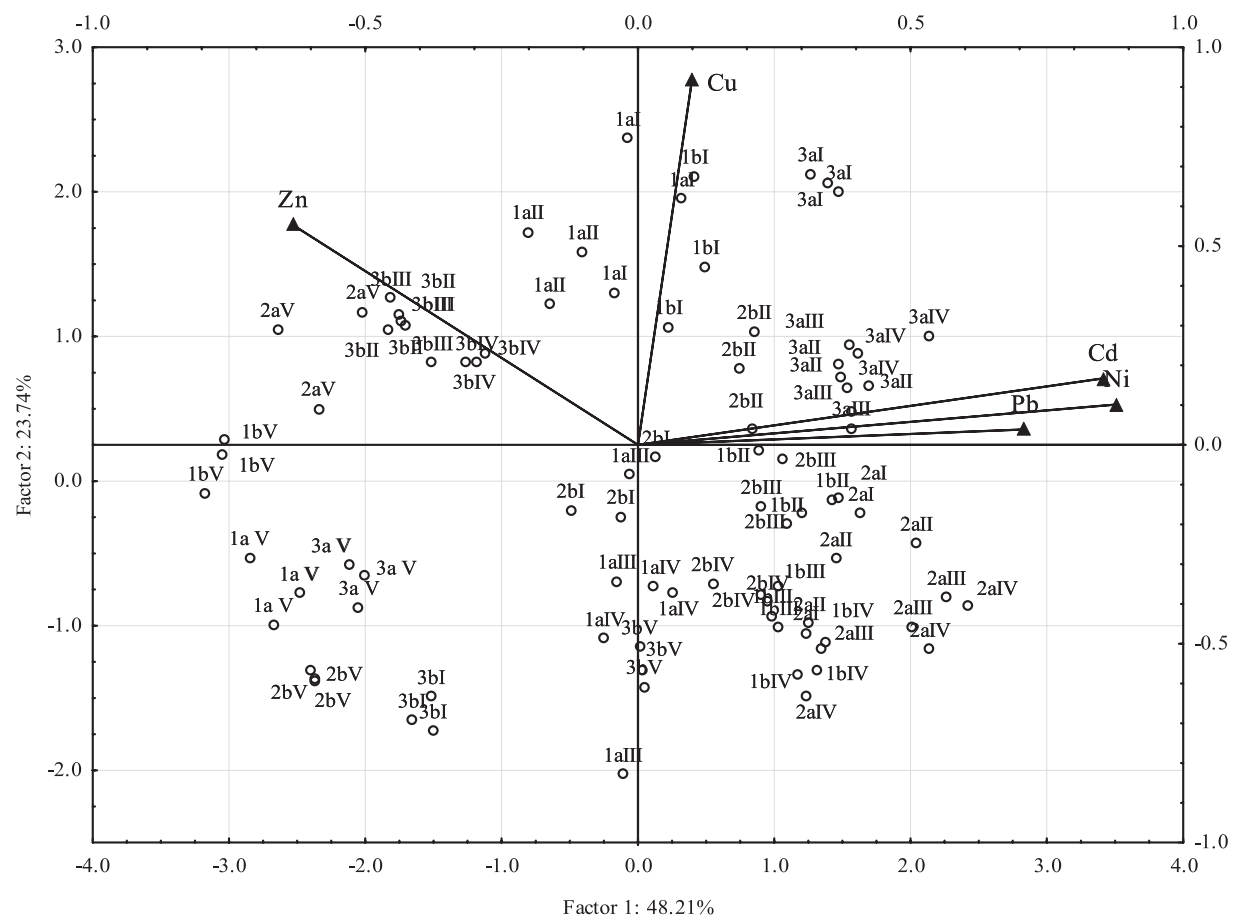

Fig. 2. Arylsulfatase resistance index in soils contaminated with $\mathrm{Zn}^{2+}, \mathrm{Cu}^{2+}, \mathrm{Ni}^{2+}, \mathrm{Cd}^{2+}$, and $\mathrm{Pb}^{2+}$, presented with principal component analysis.

soil type: 1 - loamy sand, 2 - sandy loam, 3 - sandy clay loam; soil $\mathrm{pH}$ : a - $\mathrm{pH}$ 7.0, b - pH 5.5; soil contamination degree: 0 - $0^{\circ}$, I - $\mathrm{I}^{\circ}$, II - II' , III - III' ${ }^{\circ}$ IV - IV ${ }^{\circ}, \mathrm{V}-\mathrm{V}^{\circ}$

\section{Discussion of Results}

Soil enzymes play the important role of catalysts in processes occurring in the soil, biogeochemical cycles of biogenic elements, maintaining soil homeostasis, or in the biodegradation of pollutants. Enzymatic activity is also used for evaluating the influence of pollutants on the biological quality of soils [32]. Products of reactions catalysed by them may be growth substrates for plants and microorganisms [15]. Enzymes are a sensitive indicator of biological changes occurring in the soil [33]. Determination of activity of the soil enzymes and utilisation of their activities as parameters of quality is well-grounded for many reasons. The most important of them include: strong correlation with properties of the soil, such as organic matter, activity of microorganisms, and granulometric composition; faster response to changes in parameters of the soil; and comparatively simple and fast determination methods. Arylsulfatase is an enzyme strongly correlated with the activity of microorganisms [13], as well as the organic matter content in the soil [34].

The intensity of the hydrolysis of sulfate esters is negatively correlated with the contents of lead and copper in the soil, and to a smaller extent with the contents of zinc, nickel, and cadmium [35]. Nevertheless, an increase in contamination of the soil environment with zinc and cadmium may adversely affect arylsulfatase activity. Our research also proved a significant negative correlation between the content of zinc and arylsulfatase activity.

An inhibiting influence of heavy metals on the activity of arylsulfatase was observed, similarly as in the pre- sented results, also in soil textures contaminated with copper [36]. Moreover, arylsulfatase activity depended on the type of soil texture: it is higher in loamy soils than in sandy soils [37].

Based on Tables 1 and 5, a distinct dependence of arylsulfatase activity on the physico-chemical properties of the soil may be ascertained. Decidedly, a higher activity of the enzyme was found in the SCL, in which the flumable parts content was approximately twice as high as in the other soils. A higher content of clay and silt fraction means an increase in the buffering properties of the soil textures, evident in the form of diversified $\mathrm{C}_{\text {org }}$ contents and cation exchange capacity. Thanks to this, the buffer capacity of the SCL is many times higher than that of sandy soils. Thus, the same load of $\mathrm{Zn}^{2+}, \mathrm{Cu}^{2+}, \mathrm{Ni}^{2+}, \mathrm{Cd}^{2+}$, and $\mathrm{Pb}^{2+}$ may affect the enzymatic activity in different soils to various degrees. A lower sensitivity of arylsulfatase in the soils with a higher content of SCL clay and silt fraction results from the fact that a part of the total enzyme content has probably been stabilised by soil colloids, and therefore protected from the influence of metals. In formations with conditions more favourable for the growth of microorganisms, the adverse effects of heavy metals may be significantly less noticeable and more brief than in poorer soils. Similarly as in our studies, the dependence between the activity of soil enzymes and the type of the soil texture was ascertained by Kolesnikov et al. [38].

Acidification of the soil may additionally intensify the effect of the pressure of heavy metals [39]. Low reaction of the soils may contribute to an increase in the mobility of heavy metals, and thus also to their availability to 
soil microorganisms. This fact was confirmed in our studies, based on the differences in arylsulfatase activity in the SCL and SL with a pH of 7.0, and in the same soils with a $\mathrm{pH}$ of 5.5. Simultaneously, the artificial shift of $\mathrm{pH}$ of the soil textures contaminated with $\mathrm{Zn}^{2+}, \mathrm{Cu}^{2+}, \mathrm{Cd}^{2+}$, and $\mathrm{Pb}^{2+}$ toward the alkaline reaction may also inhibit arylsulfatase activity [15], which was reflected in our studies by the differences between the activity of the enzyme in loamy sand with a $\mathrm{pH}$ of 7.0 (alkalised soil) and in that with a $\mathrm{pH}$ of 5.5 .

Prolonged contamination of the soil with zinc not only decreases the activity of arylsulfatase, but also leads to a reduction of its resistance $[40,41]$. However, the reaction of the soil has a significant influence on the resistance of the enzyme. Acidic soils contaminated with metals - with enhanced availability of these elements - disturb the action of arylsulfatase much more efficiently. As Fig. 2 shows, arylsulfatase was more sensitive to the influence of $\mathrm{Zn}^{2+}$, $\mathrm{Cu}^{2+}, \mathrm{Ni}^{2+}, \mathrm{Cd}^{2+}$, and $\mathrm{Pb}^{2+}$ both in moderately and highly contaminated soils with acidic reaction. At the same time, the effect is more pronounced in sandy formations than in loamy formations [36]. One may suppose that as a consequence of the significant dependence between the activity of arylsulfatase and its resistance, the addition of organic substances (i.e., cellulose, compost, manure, or bark) to soil contaminated with heavy metals may contribute to an improvement of both parameters [42].

\section{Conclusions}

Contamination of the soil with $\mathrm{Zn}^{2+}, \mathrm{Cu}^{2+}, \mathrm{Ni}^{2+}, \mathrm{Cd}^{2+}$, and $\mathrm{Pb}^{2+}$ in amounts exceeding their natural contents adversely affects arylsulfatase activity. The activity of arylsulfatase depends on the type of soil texture to the largest extent, then on the degree of soil contamination, $\mathrm{pH}$ of the soil, and to the smallest extent on the time of incubation of the soil.

The activity of arylsulfatase is significantly affected by the physico-chemical properties of the soil: content of silt fraction, content of organic carbon, and cation exchange capacity of the soil. Soils with a higher content of clay and silt fraction are characterised by a higher resistance of arylsulfatase to contamination with $\mathrm{Zn}^{2+}, \mathrm{Cu}^{2+}, \mathrm{Cd}^{2+}$, and $\mathrm{Pb}^{2+}$ than sandy soils.

Soils with acidic reaction contaminated with $\mathrm{Zn}^{2+}$, $\mathrm{Cu}^{2+}, \mathrm{Ni}^{2+}$, and $\mathrm{Cd}^{2+}$ are characterised by a lower resistance of arylsulfatase than soils with a neutral reaction.

The adverse effect of heavy metals on the activity and resistance of arylsulfatase may be ordered as follows: zinc $>$ copper $>$ nickel $>$ lead $>$ cadmium. Measurement of arylsulfatase activity is a valuable marker of soil quality because its activity is correlated positively with cation exchange capacity and negatively with heavy metals contamination.

\section{Acknowledgements}

Our studies were carried out within the framework of research project No. N N305 361839, funded by the National Science Centre of Poland.

\section{References}

1. JOHNSON C. C., ANDER E. L. Urban geochemical mapping studies: how and why we do them. Environ. Geochem. Hlth 30, 511, 2008.

2. BIYIK H., IMALI A., ATALAN E., TÜFUNKCI S., ÖGÜN E. Diversity of microfungi in soil polluted by cement factory, Fresen. Environ. Bull. 14, 130, 2005.

3. WYSZKOWSKI M., WYSZKOWSKA J. The effect of soil contamination with cadmium on the growth and chemical composition of spring baley (Hordeum vulgare L.) and its relationship with the enzymatic activity of soil. Fresen. Environ. Bull. 18 (7), 1046, 2009.

4. BOROS E., BAĆMAGA M., KUCHARSKI J., WYSZKOWSKA J. The usefulness of organic substances and plant growth in neutralizing the effects of zinc on the biochemical properties of soil. Fresen. Environ. Bull. 20 (12), 3101, 2011.

5. ZABOROWSKA M., KUCHARSKI J., WYSZKOWSKA J. Biological properties of soil contaminated with cadmium. J Elem. 20 (3), 769, 2015.

6. PREEM J.K., TRUU J., TRUU M., MANDER Ü., OOPKAUP K., LÖHMUS K., HELMISAARI H.S., URI V., ZOBEL M. Bacterial community structure and its relationship to soil physico-chemical characteristics in alder stands with different management histories. Ecol. Eng. 49, 10, 2012.

7. PANAGOS P., VAN LIEDERKE M., YIGINI Y., MONTARELLA L. Contaminated sites in Europe: Review of the current situation based on data collected through a European Network. J. Environ. Publ. Hlth 2013, 1, 2013.

8. LADO L.R., HENGL T., REUTER H.I. Heavy metals in european soils: a geostatistical analysis of the FOREGS Geochemical database. Geoderma, 148, 189, 2008.

9. SMITH R.S. A critical review of the bioavailability and impacts of heavy metals in municipal solid waste composts compared to sewage sludge. Environ. Int. 35, 142, 2009.

10. SIDEŁKO R. Bounding of copper, lead and chromium during composting of municipal wastes. Ochr. Sr. 26 (3), 37, 2004.

11. HENDERSON B.L., BUI E.N., MORAN C.J., SIMON D.A.P., Australia-wide predictions of soil properties using decision trees. Geoderma 124 (3-4), 383, 2005.

12. KHAN S., CAO Q., ZHENG Y.M., HUANG Y.Z., ZHU Y.G. Health risks of heavy metals in contaminated soils and food crops irrigated with wastewater in Beijing. China. Environ. Poll. 152, 686, 2008.

13. UTOBO E.B., TEWARI L. Soil ecosystem as bioindicators of soil ecosystem status, Appl. Ecol. Env. Res. 13 (1), 147, 2014.

14. BUTNARIU M. Markers, Indicators of Soil. In: Environmental Indicators, 343, 2015.

15. MORENO J.L., GARCÍA C., HERNÁNDEZ T. Toxic effect of cadmium and nickel on soil enzymes and the influence of adding sewage sludge. Eur. J. Soil Sci. 54, 377, 2003. 
16. KERTESZ M.A., MIRLEAU P. The role of soil microbes in plant sulphur nutrition. J. Exp. Bot. 55 (404), 1939, 2004.

17. CHANDER K., DYCKMANS J., JOERGNSEN R.G.J., MEYER B.G., RAUBUCH M. Different sources of heavy metals and their long-term on soil microbial properties. Biol. Fert. Soils 34, 241, 2001

18. ACOSTA-MARTINEZ V., TABATABAI M. A. Enzyme activities in a limed agricultural soil. Biol. Fert. Soils 31, 85, 2000.

19. WYSZKOWSKA J., BOROWIK A., KUCHARSKI M., KUCHARSKI J. Effect of cadmium, copper and zinc on plants, soil microorganisms and soil enzymes. J. Elem. 18 (4), 769, 2013.

20. SIWIK-ZIOMEK A. KOPER J. Changes in the content of sulphae sulphur and arylosulphatase activity in soil under potato caused by fertilization. J. Elem. 15 (1), 171, 2010.

21. LI X., SARAH P. Arylsulfatase activity of soil microbial biomass along a Mediterranean-arid transect. Soil Biol. Biochem. 35 (7), 925, 2003.

22. SIEBIELEC G., SMRECZAK B., KLIMKOWICZPAWLAS A., MALISZEWSKA-KORDYBACH B., TERELAK H., KOZA P., HRYŃCZUK B., ŁYSIAK M., MITURSKI T., GAŁĄZKA R., SUSZEK B. Monitoring of chemical composition of soil in Poland in years 2010-2012 (eds.) SIEBIELEC G. IUNG PIB Puławy, 202, 2012.

23. WIECZOREK K., WYSZKOWSKA J., KUCHARSKI J. Influence of zinc, copper, nickel, cadmium and lead in soils on acid phosphatase activity. Fresen. Environ. Bull. 23 (1A), 274, 2014.

24. ALEF K., NANNIPIERI P., TRASAR-CEPEDA C. Arylsulphatase activity. in: Methods in applied soil microbiology and biochemistry. ALEF K., NANNIPIERI P. (eds.), Academic Press. Harcourt Brace \& Company, Publishers, London, 1998.

25. ORWIN K.H., WARDLE D.A. New indices for quantifying the resistance and resilience of soil biota to exogenous disturbances. Soil Biol. Biochem. 36, 1907, 2004.

26. CARTER M. R. Soil sampling and methods of analysis. Canadian Society of soil science. Lewis Publishers, London, 1993.

27. NELSON D.W., SOMMERS L.E. Total carbon, organic carbon, and organic matter. In: SPARKS D.L. et al. (eds.) Methods of soil analysis: chemical methods. American Society of Agronomy, Madison, 1201, 1996.

28. ISO 10390:2005. Soil quality - determination of $\mathrm{pH}$.

29. PN-92/R-04016 „Chemical-agricultural analysis of the soil -
Marking of the content of assimilable zinc".

30. PN-92/R-04017, Chemical-agricultural analysis of the soil - Marking of the content of assimilable copper"

31. StatSoft Inc. (2012): STATISTICA (data analysis software system), version 10.0. www.statsoft.com

32. MASTO R.E., CHHONKAR P.K., SINGH D., PATRA A.K. Changes in soil quality indicators under long-term sewage irrigation in a sub-tropical environment. Environ. Geol. 38, $1577,2008$.

33. MUSCOLO A., SETTINERI G., ATTINÀ E. Early warning indicators of changes in soil ecosystem functioning. Ecol. Indic. 48, 542, 2015.

34. PRIETZEL J. Arylsulfatase activities in soils of the Black Forest/Germany - seasonal variation and effect of $\left(\mathrm{NH}_{4}\right)_{2} \mathrm{SO}_{4}$ fertilization. Soil Biol. Biochem. 33, 1317, 2001.

35. GÜLSER F., ERDOĞAN E. The effects of heavy metal pollution on enzyme activities and basal soil respiration of roadside soils. Environ. Monit. Asses. 145, 127, 2008.

36. WYSZKOWSKA J., KUCHARSKI M., KUCHARSKI J. Activity of $\beta$-glucosidase, arylsulphatase and phosphatases in soil contaminated with copper. J. Elem. 15 (1), 213, 2010.

37. SPEIR T.W., KETTLES H.A., PERCIVAL H.J., PARSHOTAM A. In soil acidification the cause of biochemical responses when soils are amended with heavy metal salts? Soil Biol. Biochem. 31, 1953, 1999.

38. KOLESNIKOV S.I., SPIVAKOVA N.A., KAZEEV K.SH. The effect of model soil contamination with $\mathrm{Cr}, \mathrm{Cu}, \mathrm{Ni}$, and $\mathrm{Pb}$ on the biological properties of soils in the dry steppe and semidesert regions of southern Russia. Eurasian Soil Sci. 44 (9), 1094, 2011.

39. STUCZYŃSKI T.I., MCCARTY G.W., SIEBIELEC G. Response of soil microbiological activities to cadmium, lead and zinc salt amendments. J. Environ. Qual. 32, 1346, 2003.

40. KUCHARSKI J., WIECZOREK K., WYSZKOWSKA J. Changes in the enzymatic activity in sandy loam soil exposed to zinc pressure. J. Elem. 16 (4), 577, 2011.

41. BOROWIK A., WYSZKOWSKA J., KUCHARSKI J., BAĆMAGA M., BOROS-LAJSZNER E., TOMKIEL M. Sensitivity of soil enzymes to excessive zinc concentrations. J. Elem. 19 (3), 637, 2014.

42. WYSZKOWSKA J., BOROWIK A., KUCHARSKI J., BAĆMAGA M., TOMKIEL M., BOROS-LAJSZNER E. The effect of organic fertilizers on the biochemical properties of soil contaminated with zinc. Plant Soil Environ. 59 (11), $500,2013$. 